By ALAN HOLSKE

\title{
On Meeting Interlibrary Loan Costs
}

$\mathrm{T}$

HE BOOK that I borrowed was scarcely more than a pamphlet, yet you are charging me seventy-five cents for transportation costs. I feel that this charge, like others I have paid in the past, is much too high."

These words prefaced the protest that an agitated professor at a Midwestern university recently addressed to the reference librarian at his university library. Shortly after, the professor undertook a cursory exploration of the interlibrary loan problem, expecting to accumulate evidence with which he could challenge the charge system on his own campus. The professor asked librarians at seven representative university libraries how they defrayed costs on their interlibrary loans, and upon what general principle they based their practice.

The survey showed, however, that charging interlibrary loan costs to individual borrowers is very general. Nevertheless, the professor and others who oppose the levying of such charges can find comfort in the fact that three of the librarians who were consulted are, in principle, opposed to charging interlibrary loan costs to borrowers. A fourth librarian reserved comment on the charge system at his library for personal reasons and may be considered as opposing the system. The personal views of these librarians involve them in a conflict with harsh necessity, for all happen to administer libraries where budgetary shortages compel the collection of loan costs from borrowers. One representative of this group wrote: "We regret having to do this and feel that the library should render this service, along with its other services, without charge;" and another declared categorically: "The university has the duty of providing adequate research facilities;" while still another librarian's letter alluded as follows to the budgetary malnutrition from which some university libraries are currently suffering: "I am sorry to say that we simply do not have the funds to cover this service. . . We have a very small library appropriation for a library of this size."

Only one of the libraries surveyed relieves the individual borrower of all cost for interlibrary loans. Of those which collect charges from borrowers, none charges a flat rate of so much a volume borrowed and all keep exact accounts of the cost of each loan. One librarian stated that he would like to introduce a flat rate of twenty-five cents a volume so that the charge system would bear less heavily upon borrowers in the more impecunious academic brackets.

One of the valid arguments against a system of charges is the burden it imposes upon the graduate student and part-time assistant. A graduate student who is assessed all transportation costs on a loan may have to pay almost a dollar for each volume borrowed, if the supplying libraries require the transportation of their books by express. If a student has to borrow a large number of books to complete a thesis project, his resultant liability may in some circumstances be staggering. Instances could be cited in which consideration of 
these costs has stalled a promising research project. Where a charge system is in operation it is understandable if faculty members dissuade their students from enterprises involving books not in their own university libraries, and it is equally understandable if faculty members themselves avoid such projects.

One librarian criticized the requirement made by some libraries that the books they send out on interlibrary loan be forwarded by express, since this mode of transportation increases lending costs. Parcel post is fast and reliable, this librarian declared, and the current low book rate was introduced to stimulate the circulation of books, while the minimum express charge of thirty-five cents a package is made presumably to discourage the shipment of small packages, which are unprofitable for an express company to handle.

Three of the libraries provide no alternative to collecting transportation costs directly from the borrower. However, certain alternatives are in operation at some institutions. One library charges incoming transportation and insurance costs to the borrower and defrays the return costs in some other manner. Two libraries sometimes reclaim loan costs from university research funds, while one sometimes charges loan costs to the book purchase fund of the borrower's academic department or to its miscellaneous fund allowance. Of these alternative procedures, deducting loan costs from departmental book funds alone seems open to criticism. If budgetary restrictions force a university library to seek reimbursement for loan costs from the outside, the various academic departments will doubtless be proportionately pinched, and their limited book funds should be spent only to acquire books which will obviate other loan requests in the future.

Some libraries consistently examine requests for interlibrary loans to determine whether they reveal gaps that should be filled by purchases. One library microfilms a number of the books for which loan requests are made.

Three of the librarians consulted uphold on principle the charging of interlibrary loan costs to borrowers. All of them hold the same point of view : they want to curb what they regard as "abuses of the loan privilege." The only one of their number who defined "abuses" called them "trivial" requests for books that are "not actually needed," but none of the librarians who mentioned "abuses" gave an estimate of the percentage of loan requests at his own library that he had at any time considered unnecessary, nor did any declare what percentage of requests he would consider necessary and justified.

The concept of "abuses" seems to this writer to need clarification because, as now applied, it hinders a full appraisal of the interlibrary loan problem. Charging loan costs to all borrowers in order to deter a certain percentage of borrowers from making requests that might seem trivial imposes a penalty on borrowers whose requests might on strict inquiry be found necessary. No one can determine categorically what books a man facing the challenge of a new idea or of a developing research problem will or will not need; ordinarily a reader can determine whether a book is of value to him only after he has sampled it. For that reason the phrases "trivial requests" and "necessary loans" are of dubious value.

These notions obscure a deep issue which should be recognized: Do we want a maximum free circulation of books or not? Can a bookman wish to restrict the circulation of books or prevent any reader from obtaining a book he may wish to examine? To stand between a book and its potential reader is inconsistent with the nature of the university, which is epitomized in its library. 
The use of books is the one fundamental activity of a university, of which its library is therefore the vital center. "A true university," Carlyle said, "is a collection of books." To charge for football tickets is one thing: football is an extraneous growth upon the university. For centuries universities flourished without pigskin, but parchment and vellum-books-have always been the magnetic center that has brought students and teachers together.

A historical argument, drawn from the history of American education and civilization, can be brought forward to oppose a limitation of the circulation of books. Within the academic community the university library represents the American institution of the free public library. Free schools and free books express an inherent tendency in American civilization which should be recognized now and at all times as a guide to liberal action. Charging borrowers for library services vitiates this principle; if a borrower can now be charged for onc kind of service, he could eventually be charged, with perfect logic, for any service entailing cost.

A logical argument against a system of charges for interlibrary loans has been advanced: as long as universities appropriate funds to promote research, charging loan costs to borrowers is anomalous since it constitutes a direct discouragement to research.

Essentially, the problem is not how to curb abuses and eradicate trivial requests, but rather how to enlarge the facilities for the circulation of books in order to meet the increasing demand for them. That such enlargement is an urgent need was made evident by several communications to the writer, among them a letter from a librarian who stoutly defends the charging of interlibrary loan costs to borrowers because he believes that is the simplest way to restrict the growing volume of loan requests, which could easily lead to the breakdown of the entire loan system. While this correspondent pleads only for limiting demand and says nothing of enlarging facilities, his letter corroborates communications received from other librarians which, when pieced together, form the picture of a problematical situation.

America has become generally hungry for books and book learning, and educational institutions have vastly increased their student registrations and faculty membership. Some university libraries have been unable to increase their appropriations in a steady ratio with this growth, and they are now seriously hampered by budgetary deficiencies. Libraries have also been affected by qualitative changes in college faculties; faculty members are now universally required to hold advanced degrees and to demonstrate prowess in specialized research by continuous technical reading and publication. In addition, the character of scholarship has changed; the broader learning of an earlier day, which was anchored mainly to standard and basic works, is being displaced by a microscopic scholarship. In the humanities and social sciences a highly refined specialization has put out vast numbers of detail studies, monograph series, journals, and minutely specialized theses. These factors have conspired to increase the burden on university libraries in a staggering geometrical progression.

Meanwhile, until the day when all university libraries will control resources equal to the demand upon them, the pressure of loan requests can be relieved by palliative measures that will obviate as many such requests as possible. Many libraries already make a practice of thoroughly revising and modernizing their stocks in various fields periodically and in collaboration with the academic departments concerned. Where past neglect or impecuniosity have passed on badly balanced or deficient stocks, special efforts are being made to raise funds to 
remedy the deficiencies which loan requests. or a systematic survey of stocks may happen to reveal. To counterbalance budgetary shortages, reconstruction or expansion may be promoted by acquiring books in microfilm whenever possible.

Rebuilding or expanding stocks to obviate future loan requests entrains questions as to what books are desirable, standard, or indispensable, and hence to be selected before others for acquisition from limited funds. How far should limited moneys be spent in developing collections in growing fields like Russian and in foreign literatures, for example, in which most American libraries cannot be expected to equal those abroad?

Librarians and members of academic departments need one another's aid and counsel in answering these questions and at some universities there has been too little such fruitful collaboration in the past. This collaboration might be directed toward the compilation, by members of the various academic departments in consultation with their librarians, of selective standard bibliographies in their respective fields, which would summarize and compress existing standard bibliographies. Besides serving as a guide to an effective expansion of stocks these selective bibliographies could be made the basis of a new system of loan charges. Volumes listed, if not yet in a university library, would be procured without attendant cost to the borrower, and volumes not on the list could be provided in return for payment of costs by the borrower or, preferably, from research funds.

National bibliographies of similar scope would provide a uniform foundation for the interlibrary loan system. Carefully compiled, they could become master bibliographies which would remain standard over a long period. If provided with certain supplementary materials they might evoke sufficient interest among teachers and students to justify their publication as accepted handbooks in various fields. Among desirable supplements, summaries of the history of research in diverse subdivisions of general fields might be mentioned. Bibliographical and historiographical handbooks of this sort would collate and synopsize materials now scattered in various handbooks.

Besides providing a uniform standard minimum to guide librarians everywhere, handbooks like these would be useful in facilitating the often laborious orientation of major and graduate students in their fields of study. That guidance of even the simplest kind is needed has been demonstrated by the recent appearance at several universities of mimeographed skeletal reading lists for major and graduate students. Such handbooks could also be useful in presenting average standards of scope and intensity for senior college and graduate courses, among which there is now great variation.

At any rate, the specific question of interlibrary loans has been found to broaden into a larger and knottier problem. This concerns the expansion of book-providing facilities and their intimate coordination with the various fields of study, the cultivation of which depends on easily accessible book stocks. Campus campaigns for more books rather than for more buildings are overdue. It must be made widely known that in the current phase of American educational and cultural development broader policies in library financing are a necessity.

Meanwhile, the borrowers of books on interlibrary loan should be relieved of money penalties whenever possible. The free circulation of books is today more than ever an important expression of American civilization, and it should be American policy, everywhere and at all times. 